\title{
EMISSION ALLOWANCES - RECOGNITION AND THE FUTURE
}

\author{
[Emisní povolenky - Vykazování a budoucnost] \\ Hana Březinová ${ }^{1}$, David Trytko ${ }^{2}$

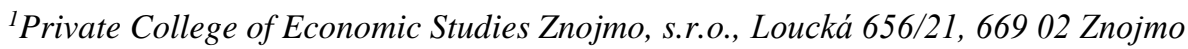 \\ Email: brezinova@svse.cz \\ ${ }^{2}$ Private College of Economic Studies Znojmo, s.r.o., Loucká 656/21, 66902 Znojmo \\ Email: david.trytko@roedl.com
}

\begin{abstract}
Emission of the greenhouse gases has a significant impact on the environment of the whole planet. Innumerable international plenary sessions have agreed only on partial solutions. The signatory countries came up with the instrument which should improve the air quality- the emission allowances. The politicians and environmentalists involved in the Kyoto Protocol and subsequent Paris Agreement have negotiated emission reductions. Achievement of this goal is established for years $2005-2030.43$ $\%$ of current greenhouse gas emissions should be reduced. Each allowance represents the right to emit one tonne of carbon dioxide $\left(\mathrm{CO}_{2}\right)$ or the equivalent amount of two more powerful greenhouse gases, nitrous oxide $\left(\mathrm{N}_{2} \mathrm{O}\right)$ and perfluorocarbons (PFCs). Allowances are distributed among individual countries, which allocate them free of charge to plants, factories and other fixed installations. These emission allowances can be the subject of trade between these operators. All these facts result in questions related to the accounting methods. How many allowances are needed? Should they be recognised as an asset? Is their price regulation necessary? Can emission allowances reduce greenhouse gases or are government subsidies and compensations - alternatively carbon taxes - more suitable for this purpose? Is the business environment more or less destroyed? The goal of this article is to contribute by critical discussion to easier, fair and true recognition of emission allowances.
\end{abstract}

Keywords: emission allowance, intangible asset, Kyoto Protocol, Paris Agreement, right.

JEL classification: E20, E22, F64, F65, G12, H25, M41

Received: 14.9.2020; Reviewed: 15.9.2020; 16.10.2020; Accepted: 16.12.2020

\section{Introduction}

The goal of this scientific article is to capture principles of Kyoto Protocol and Paris Agreement leading to a reduction of greenhouse gases emitted by plants, factories and other fixed installations, including critical analysis of available accounting methods during recognition process for a typical accounting entity, based on the economic substance of allowances. After more than twenty years of allowances usage - before the start of the fourth trading period (phase 4: 2021 - 2030) -some challenges and needs of improvement are to be stated. Emission rights to emit greenhouse gases have been capitalised as a non-current - intangible asset within their user's balance sheets with highly significant impact due to considerable price volatility in long term trading run. Their surplus - particularly during the trading period 3 - can be confusingly interpreted as a positive impact caused by energy savings while it is noteworthy that allowances capitalisation effect in polluters balance sheets (them after as BS) leads subsequent to energy price increases. Is the approach of experts to the greenhouse gas reduction correct? What development can be expected after 2021 ?

\section{Legal framework of emission allowances issuing}

A milestone in global efforts in combat climate change is the Kyoto Protocol to of the United Nations Framework Convention which entered into force on 16 February 2005. (February 02, 2005). 83 signatory countries committed themselves to reducing greenhouse gas emissions 
between 2008 - 2012 on average less by 5,2\% compared to emissions in 1990. The commitment of the Czech Republic was established at $8 \%$. The Kyoto Protocol was determined till $2012[6,7]$.

The European Union came up with an instrument which should reduce greenhouse gas emissions, including Emissions Trading System - the emission allowances. Since 2005, the total amount issued by Member States determines the total volume of greenhouse gases produced in EU countries. The EU Commission established this total volume according to the industry demandingness on carbon emissions of each EU Member. EU Members allocate these allowances to installation operators producing greenhouse gases in their countries. If the emissions are reduced, the polluting company can keep the spare allowances to cover its future needs or else sell them to another company that is short of allowances.

Parties to the Kyoto Protocol adopted an amendment in December 2012 in Doha- the Doha Amendment - which establishes new emission reduction targets for the second commitment period (2013 - 2020). It obliges the EU and its Member States to reduce collective greenhouse gas emissions by $20 \%$ compared to 1990 levels. This obligation till 2020 affects approximately $15 \%$ of global emissions considering that the Doha Amendment is not binding for developing countries (PR of China, India, Brazil etc.).

Parties with commitments under the Amendment to Kyoto Protocol are allowed to trade their emission allowances organized by International Emission Trading, IET, also known as cap and trade. The European Union Emission Trading Scheme (EU ETS) is the world's first major carbon market and remains the biggest one. The Czech Republic is its member $[6,7]$.

In October 2014, the representatives of EU Member States negotiated the 2030 climate and energy framework which includes EU-wide targets and policy objectives for the period from 2021 to 2030. At the end of 2015 in Le Bourget, near Paris, France, the Paris Agreement was negotiated by representatives of 196 States at the 21 st season of the Conference of the Parties within the United Nations Framework Convention on Climate Change (UNFCCC - COP 21). In February 2020, all UNFCCC members signed the agreement which represented a consensus of the representatives of the 196 attending parties. The agreement enters into force thirty days later when joined by at least 55 countries which together represent at least 55 percent of global greenhouse gas emission [8].

The European Council assessed critically the development of emission reduction, revised current EU ETS due to a decreasing demand on emission allowances caused by their high surplus and the target of greenhouse gas emission reduction by $40 \%$ till 2030, and the Market Stability Reserve (MSR) began operating from January 1st, 2019. The "backloaded" allowances (900 million allowances withdrawn from the market, at least until 2019), will be placed in the MSR instead of the carbon market. Two new funds will be established: The Innovation Fund and the Modernisation Fund ${ }^{1}$ (for the energy sector).

Nevertheless critical meanings can be noticed, e.g. Ruf (2017) argues that the EU ETS can never be completely adapted to the requirements of the free market as the market will never function perfectly. For this reason, the revisions of the EU ETS will also not result in satisfying policy outcomes and will not lead to a success of the system as long as its design remains.

\footnotetext{
${ }^{1}$ https://www.consilium.europa.eu/cs/policies/climate-change/reform-eu-ets/
} 


\subsection{Normative framework in the European Union}

The corpus of legislation in the EU - the Directive 2003/87/ES with its amendments is the legislative act of the EU with the target to implement and harmonise the cap and trade system of emission allowances. The form and the conditions of EU ETS are regulated in the Directive 2009/29/ES for the Third Phase 2013 - 2020. Based on this directive, the following norms were established:

- the Commission Decision of April 27, 2011 - No 278/2011/EU - determining transitional Union-wide rules for harmonised free allocation of emission allowances,

- the Commission Regulation (EU) No 601/2012 of 21 June 2012 on the monitoring and reporting of greenhouse gas emissions (hereinafter referred „Commission Regulation $\left.(\mathrm{EU})^{6}\right)$

and other announcements, methodological publications and guidelines - see list of literature.

\subsection{Legal framework in the Czech Republic}

Based on global development and according to the Czech international legal obligations, the Act No. 695/2004 Sb., on the trading conditions of emission allowances was adopted, then predominantly substituted with the Act No. 383/2012 Sb. (hereinafter referred to as „Act or Allowance Trading Act"). The Act merges all relevant EU legal regulations including Directives, Regulations, announcements and guidelines, and is in accordance with the United Nations Framework Convention on Climate Change and Paris Agreement as well.

The implementing decree No. 192/2013 Sb. to the Act lays down applications for allocation of allowances for aircraft operators and permits to emit greenhouse gas.

\section{Distribution process and utilisation of emission allowances}

For better understanding of accounting methods for recognition of the EU emissions trading scheme, a deeper knowledge of distribution process and utilisation is necessary. Due to the limited extent of this article, the scientific literature search and historical data are abandoned.

\subsection{Utilisation of emission allowances}

Since the Third Trading Period - phase 3 - an overall limit for the amount of allowances was established on the EU level, not on the national level. The conclusion of this new fact is that the MSR - back-loading of auction volumes is decided only by the Commission.

\subsection{Distribution of emission allowances}

The purpose is to harmonise all national allocation plans and, instead of free of charge allowances distribution, they should be obtained through an auction. During the phase 3, it was agreed to use a part of emission allowances (300 million) to fund an innovative low-carbon technology, focusing on demonstration of environmentally safe Carbon Capture and Storage (CCS) and innovative renewable energy technologies on a commercial scale under the EU programme NER 300. NER 300 is currently one of the world's largest funding programmes for innovative low-carbon energy demonstration projects. The programme is designed as a catalyst for the demonstration of environmentally safe carbon capture and storage and innovative renewable energy technologies on a commercial scale within the European Union. The programme is managed by the European Commission ${ }^{2}$.

Phase 4 starts on January 1, 2021 and ends on December 31, 2030. The EU should allocate 6.3 billion emission allowances free of charge, worth 160 billion EUR.

\footnotetext{
${ }^{2}$ https://www.interregeurope.eu/decarb/news/news-article/8776/the-ner-300-programme/
} 
The EU ETS data viewer provides aggregated data by country, by main activity type and by year on the verified emissions, allowances and surrendered units of more than 15,000 stationary installations reporting under the EU emission trading system, as well as 1,500 aircraft operators. This updated methodological approach of cap and trading scheme will have a significant impact on the volume and financial amount of allowances issued by each country, and subsequently, by each polluter. The valuation of allowances obtained free of charge at replacement cost will significantly increase the total amounts of BS lines containing recognised emission allowances acquired on market. An increased price volatility with unpredictable future development of allowances obtained through an auction increases the relevant risk of recognised BS position with the following significant impact on profit or loss.

Picture No 1 represents the amount of issued emission allowances.

Figure 1: Number of issued emission permits in years

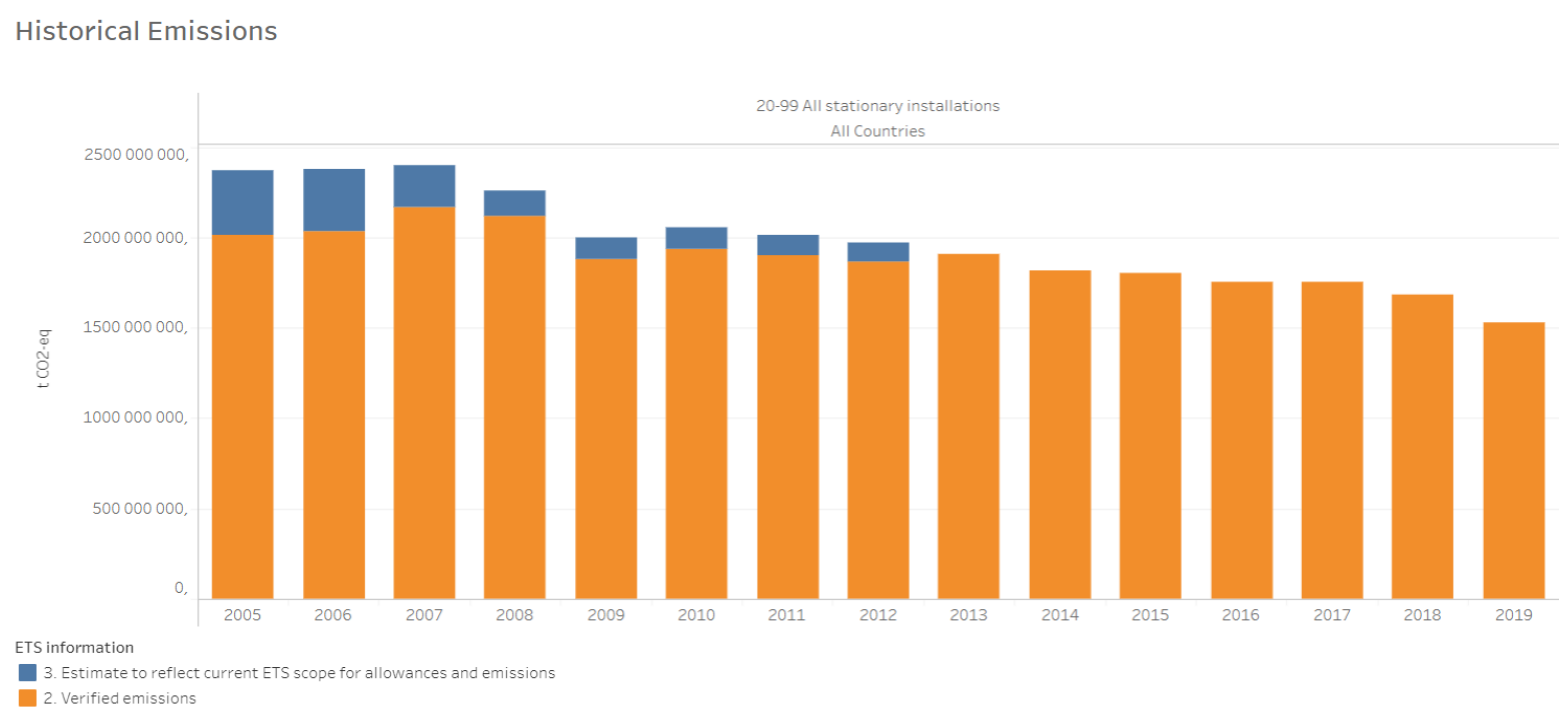

Source: website European Environment Agency: EU Emissions Trading System (ETS) data viewer [online][seen on June 18, 2020]. Available under https://www.eea.europa.eu/data-and-maps/dashboards/emissions-tradingviewer-1

In accordance with Article 10 and Direction EU ETS (FAR) the Commission issued a set of guidelines which are quite sophisticated. Following flowchart shows a reference between relevant documents and the way to find them. 
Figure 2: Set of guidelines

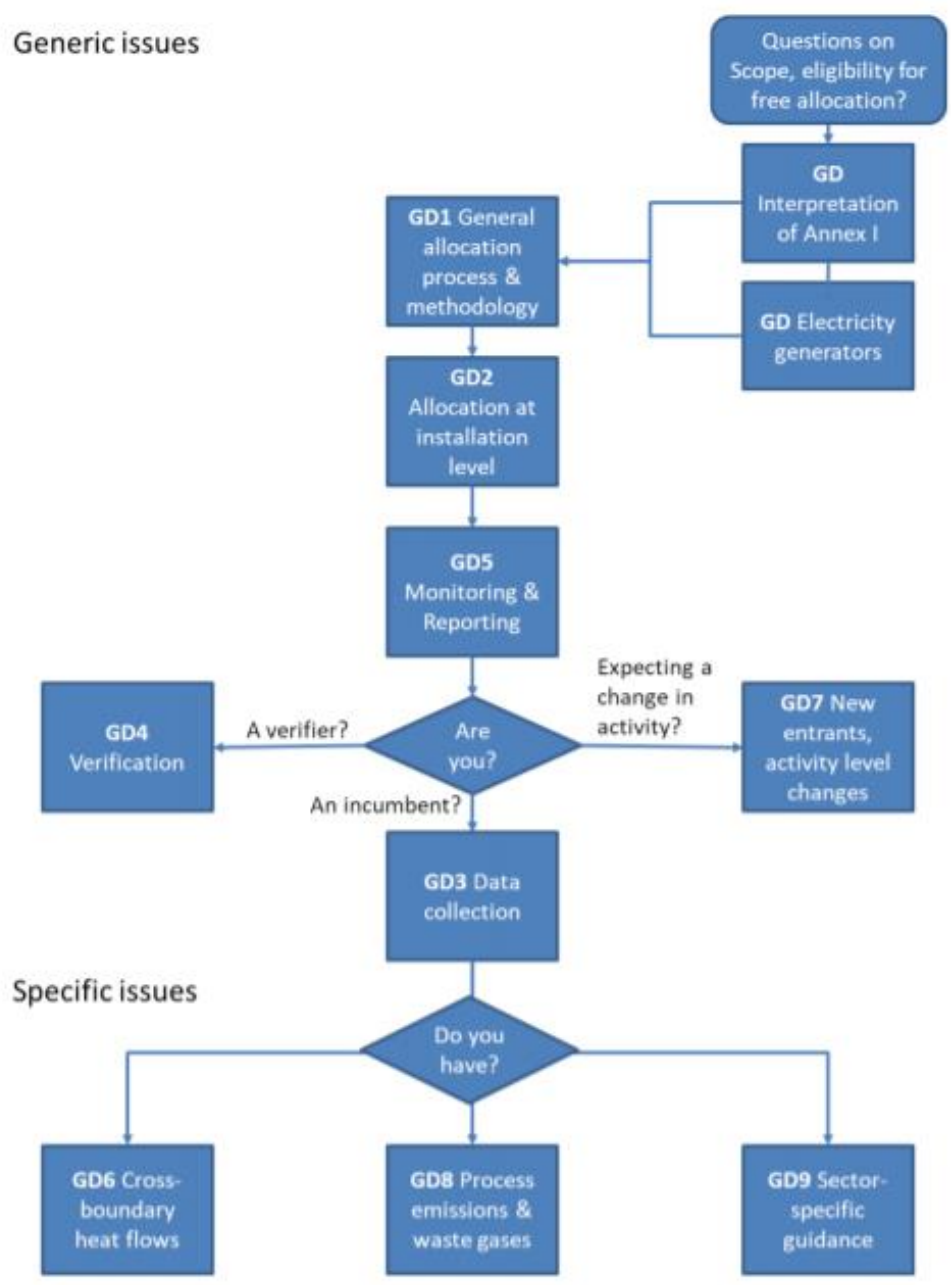

Source: web site EUROPEAN COMMISSION: Overall guideline for emission allowances distribution [online] [seen on January 31, 2019]. Available under https://www.mzp.cz/C1257458002F0DC7/cz/pridelovani_povolenek_metodika_osm/\$FILE/oeokMetodicky_pokyn 1-20190401.002.pdf

Greenhouse gas emissions permit will be obtained by polluter based on application, using a relevant form issued by The Ministry of the Environment of the Czech Republic. The applicant becomes concurrently a member of ETS. Since 2005, four trading periods - phases $1-4$ have been set by the EU ETS:

- the first trading period from January 1, 2005 till December 31, 2007,

- the second trading period from January 1, 2008 till December 31, 2012,

- the third trading period from January 1, 2013 till December 31, 2020 and

- the fourth trading period from January 1, 2021 till December 31, 2030.

Currently there are 309 polluting facilities operated by 209 licensees in the Czech Republic. The sector covers the production of electricity and heat, energy intensive industry and air transport. Fuel combustion represents $80 \%$ of all emissions under the EU ETS, less than $9 \%$ 
of other activities is the production of pig iron and steel and $3.5 \%$ is the production of cement clinker, other processes are marginal ${ }^{3}$.

Approximately less than $75 \%$ of all emission allowances in the Czech Republic is allocated free of charge, about $27 \%$ is obtained on the market.

An applicant (polluter) receives allotted emission permits by register administrator free of charge each year at the end of February at the latest. Those emission allowances can be used by polluters due to greenhouse gases emission or to be ceded o third parties (capitalisation equity contribution - is not allowed) [12]. All mentioned facts are essential for the choice of suitable accounting method and emission allowances recognition.

\subsection{Utilisation of emission allowances}

An emission allowance by public law is a kind of other property - an intangible asset which epresents the right to emit one tonne of carbon dioxide by the holder - polluter - power plants, factories and other fixed installations, aircraft as well. One tonne of carbon dioxide means, according to the EU Directive, one metric tonne of carbon dioxide or other greenhouse gas than carbon dioxide with an equivalent global-warming potential as carbon dioxide.

An operator of polluting installations generally has two ways to use an emission allowance. Basic rule is to use the allowance to pay for pollution, secondary it can be used for trading - not used ones can be converted into money, in case of allowance shortage they are to be bought.

\subsubsection{Surrender of allowances}

By 30 April of the current calendar year at the latest, the operator of each installation surrenders a number of allowances equal to emissions produced from installation in the previous calendar year, based on monitoring, reporting and verification of the emissions. Only allowances addressed for the relevant trading period can be used for this purpose [12]. Described circumstances are necessary for calculation and recognition of estimated payables according to the factual amount of vented emissions at the balance sheet day.

\subsubsection{Trading}

The OTE a.s. administers the National Register of Greenhouse Gas Emissions ${ }^{4}$. This company, fully owned by the Czech Republic, ensures electricity and gas trading as well as emission allowances trading according to the Act.

\section{Emission allowance as an asset}

Trying to find a fair and true method for allowances recognition in financial statements in literature, signatories of Kyoto Protocol have found inspiration in setters of International Accounting Standards. Although a separate standard was not issued by them, they did try to set down basic accounting principles within an interpretation (IFRIC).

In December 2004 the IASB issued a draft of IFRIC 3 Interpretations on IAS. The Interpretation to be adopted by participants in a 'cap and trade' scheme focuses on the accounting of emission allowances. The Interpretation specifies that ${ }^{5}$,

- rights (allowances) are intangible assets that should be recognised in the financial statements in accordance with IAS 38 Intangible Assets.

\footnotetext{
${ }^{3}$ https://www.mzp.cz/cz/emisni_obchodovani

4 www.ote-cr.cz

5 https://www.iasplus.com/en/standards/ifric/ifric3
} 
- when allowances are issued to a participant by government (or government agency) for less than their fair value, the difference between the amount paid (if any) and their fair value is a government grant that is accounted for in accordance with IAS 20 Accounting for Government Grants and Disclosure of Government Assistance.

- as a participant produces emissions, it recognises a provision for its obligation to deliver allowances in accordance with IAS 37 Provisions, Contingent Liabilities and Contingent Assets. This provision is normally measured at the market value of the allowances needed to settle it.

In June 2005 the IFRIC discussed two approaches - a proposed amendment to IAS 38 Intangible Assets that would create an additional category of intangibles measured at fair value through profit and loss, and a proposal from EFRAG as to how hedge accounting could be used to resolve the mismatch issues created by IFRIC 3. In July 2005 the Board of IASB decided to withdraw IFRIC 3. The Board's Work Plan has indicated that reconsideration of IFRIC 3 "has been deferred pending the conclusion of work on other relevant projects". No subsequent decision by the IASB was provided.

Nations at present are following dissimilar approaches for the reduction of greenhouse gas emissions level and achieve national carbon emissions reduction targets. Carbon Emission Trading Schemes have emerged as one of the highly common system in the carbon market internationally, which offers various multifaceted accounting concerns (Warwick and $\mathrm{Ng} 2012$ ).

After the withdrawal of IFRIC 3 and in the absence of any international guidance on accounting for carbon emission allowances; a number of different practices have appeared (Mackenzie 2009).

Since October 5, 2005, the Czech Directive No 97/2005 [12] regulates recognition of emission allowances under long term assets - intangible rights to emit greenhouse gases - without any capitalisation limit. The accounting and posting methods are partly standardised in the Czech Accounting Standard No 013 and analysed in several professional articles, but without any additional legal framework.

\subsection{Allowances Identification}

On the basis of legal norms, an emission allowance is a polluter's right to emit one tonne of greenhouse gases. Consequently, it is possible to identify a right - an intangible thing according to the Article No 496, para. 3 of the Czech Civil Code.

The accounting Directive lists emission allowance as an intangible non-current asset without any capitalisation limit.

\subsection{Valuation}

Allowances obtained free of charge are recognised according to the Czech Act on Accounting and the Czech Accounting Standard No 013 at replacement cost. Allowances allocation is provided by the administrator of the National Register of Greenhouse Gas Emissions (OTE) and each operator receives an individual amount of allowances according to the National Allocation Plan developed by the Czech Ministry of Environment. As mentioned above, allowances free of charge are recognised at replacement cost. For this purpose, the market values are available e.g. on EEX website - European Energy Exchange in Leipzig, Germany (www.eex.de) due to free trading approach (Ryneš 2019).

Valuation of acquired allowances is provided at acquisition cost E.g. the company ČEZ ESCO conducts trade with emission permits and offers: 
a) products

- spot allowances

- futures allowances

- $\quad$ product funding

b) trading

- live price - at current price on e.g. ICE Future Europe

- settlement price - at average daily price

- limited price - at maximum or minimum price on the market.

Due to trading in EUR, the acquisition price has to be translated to CZK. According to the fixed asset valuation method and principle - see article 47 of the Czech Accounting Directive subsequent FX translation differences are not a part of acquisition cost.

Figure 3: Price development of emission allowances (in EUR)



According to asset-management and valuation method of allowances disposals are two approaches available - the FIFO or with weighted average value. The disposals from allowances register are withdrawn by the OTE according their exact individual identification.

\subsection{Future economic benefit}

To meet the capitalisation criteria as an asset for emission allowances is important to analyse their future economic benefit.

The most important matter is to identify who has profit or utility resulting from an emission allowance. How can be benefit determined? If an accounting entity receives an exact allowances amount as needed for settlement of emission obligation for free of charge, the applied accounting method ensures no impact on profit or loss account. The future economic benefit can be also measured by the government (Czech budget income from allowance trade for 2018 amounts to CZK 15 billion, 2019 already CZK 16 billion) - therefore by the society or the world. If emission permits can be held for trade, an accounting entity can obtain profit - gain from allowances sale over their acquisition cost. 


\section{Recognition of emission allowances in balance sheet}

According to the current Czech accounting rules and principles, allowances are recognised as Non-current Assets - Long-term Intangible Rights.

\subsection{The right}

Resulting from the current emission allowance definition, the right is incorporated in permission to emit an equivalent of one tonne of carbon dioxide, or an equivalent, in the air by single operator. This right can be part of either long-term or short-term assets. Czech accounting principles regulate only non-current asset recognition as Other Non-current Intangible Assets. Due to the significance of this item in terms of amount in the balance sheet, use of separate balance sheet line is recommended.

\subsection{Expected useful life - holding period}

The holding period is dependent on the actual trading period of each allowance emission. It is further limited by the due date of obligation settlement of each emission. The period is also influenced by intention to trade with excessive amount of emissions (or temporarily needless emissions). Therefore, not all mentioned cases meet the criteria for a long-term assets recognition.

\subsection{Recognised amount}

In the balance sheet the allowances obtained free of charge are recognised in brutto values in Czech currency using replacement cost method, in case of acquired allowances using acquisition cost method. The FX translation into CZK is carried out at the execution date, so that asset remains to be recognised in Czech currency.

\subsubsection{Impairment}

Fair value of allowances is quite oscillating in the long run, which can be seen not only on picture 3 , but also in our circumstances on picture 4 . Balance sheet recognition is carried out under long-term assets without capitalisation limit and any amortisation. In case of short-term impairment, a short-term value correction - allowance - should be used. The valuation increase should be described in the Notes to the Financial Statements.

Figure 4: Average value of emission allowances according Czech Energy Regulatory Office

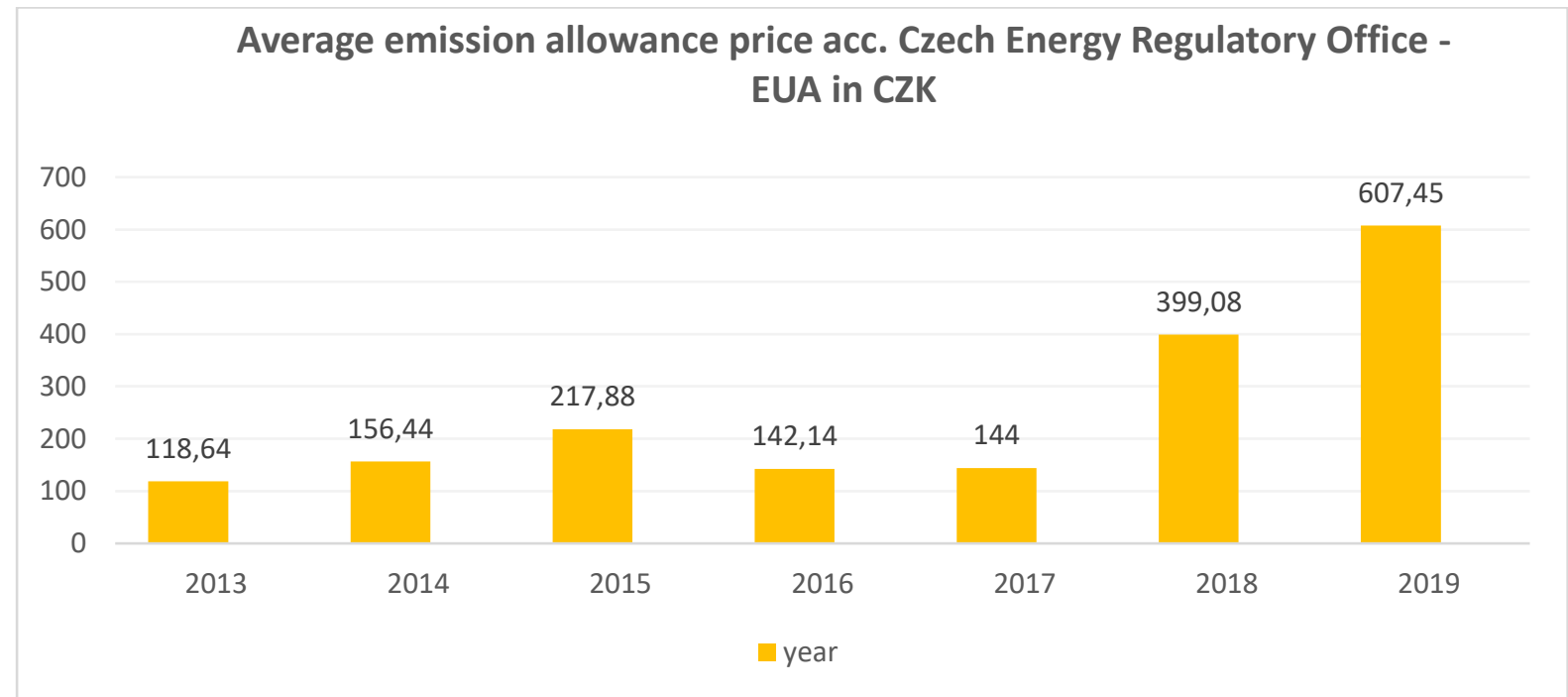

Source: Trends and estimated development in the heating industry. [online][seen March 4, 2020]. Available under http://www.konference.org/vyvoj_odvetvi_energetiky_2020/prezentace_recniku/Vecka.pdf 


\section{Accounting and posting methods}

\subsection{Acquisition}

Emission allowances can be obtained free of charge or by an acquisition on the market.

An increase of allowances received for free can be posted directly under the respective balance sheet long-term asset account (account class \#01 - Long-term Intangible Assets). It is possible to use two accounts - either account No. 019 - Other Non-current Intangible Assets, or the account No. 015 - Emission Allowances, which can be found as separate balance sheet position of long-term assets. Free of charge acquisition is methodically considered as a government subsidy - grant (posted under credit account No. 347 - Other Subsidies).

In case of acquisition on the market, a contemporary acquisition accounts should be used account No. 041 - Intangible Fixed Assets Under Construction, where cumulated acquisition costs form final acquisition cost, followed by the transfer to the relevant asset account.

\subsection{Surrender - emission allowances settlement}

In case of settlement of the allowances the disposal of allowances represents an operating expense. The entity then posts government subsidy as Other Operating Income, which amount is limited by the value of emissions obtained free of charge, meaning there is no impact on final result, thus EBIT remains unchanged.

If the entity identifies a deficiency of allowances at the date when it is obliged to submit the amount of consumed allowances to Ministry of the Environment, then a certain amount of risk has to be taken into account. Although IFRIC 3 suggests creating provision, methodically it is more appropriate to use Estimated Payables (account No. 389). Reason for this approach is the specific knowledge of purpose and due date (April 30 the following year). The estimate is only created in the amount of required allowances - to be surrendered.

Sale of unused allowances splits in two steps; Disposal of Fixed Asset (credit) against the expense account No. 541 - Net Book Value of Fixed Assets Sold, and the revenue posted on Accounts Receivable (debit) against the revenue account No. 641 - Sales of Fixed Assets.

\section{Other methodological approaches}

\subsection{Corrections in the Czech Republic}

Vrbová (2020) states that for Czech companies the price of electricity increased due to the reform of emission allowances trading. In the last three years the price of EUA has increased approx. from EUR 5 to EUR 27. Finally, after many years the allowances met their purpose. Consequently, the price of electricity went up as the companies producing electricity from fossil fuels mirrored the cost incurred into the wholesale prices. However, the Government responded with a system of compensation in favour of the biggest energy producers each year (in order to reduce the price for consumers).

\subsection{Proposal of the United Kingdom}

Soon, The UK leaves the European allowances trade system and will prepare its own solution, which would replace the EU ETS starting from 2021. Approximately one thousand operators will be affected. Currently, price of GBP 15 per one tonne of carbon dioxide is in discussion. Majling (2020) states: „Even though the integration of allowance trade system is preferred, other alternatives are investigated by the British government. So called carbon tax could be implemented, which can replace the existing trade system as whole and would guarantee minimal fees for emission allowances. More details incl. consultancy process are planned to be announced later this year by the government". 


\subsection{Studies evaluating clime improvements worldwide}

Tauchanova (Prague 2017) proves in her study, despite significant imperfections of the ETS, their modifications are difficult and not too easy to be put into effect. Due to historical institutionalism, a consecutive development is locked and transaction costs for any change are consequently increasing. The current ETS participants are concerted by upcoming trading period seriously which causes effort to minimize negative impact on their financial position.

The World Bank Group study (2019) even conducts a survey of 57 initiatives and movements to impose a charge for air pollution on national and regional level and properly describes arrangements and methods provided by each country.

\section{Conclusion}

The efforts to reduce the volume of emission allowances caused by a glut in the market, subsequent transfer of a part of allowances to the Market Stability Reserve and a sharp increase of their price significantly affects the financial statements of the facilities operators. Environmental policy decisions under the Paris Agreement have an uneven impact from the global perspective. This environmental activity mainly concerns the countries of the EU. The financial statements of European companies, usually with a significant item of intangible assets at this moment, are incomparable with other business corporations operating on global capital markets. However, it is not clear that emission allowances can really be considered intangible non-current assets, as it is questionable whether they bring future economic benefits to the entity.

Brexit is leading the United Kingdom not only to leave the EU UTS, but also to consider whether it is appropriate to find another emissions trading system or to deal with the situation through a carbon tax. Due to significant increase of energy price caused by rising prices of emission allowances, the Czech Government considers to provide annual compensation to the largest operators. This will cause an erosion in recognition of the energy prices to the correct level of full own costs, taking into account negative externalities related to their production as well.

From a global point of view, one of the biggest players worldwide - the U.S.A. significantly transformed their power production/energy policy during last ten years. They became selfsufficient, President Trump has strongly criticized the 2015 Paris Agreement on climate and finally exited Paris Agreement, which caused cardinal impact on environment quality regulation worldwide. Newly elected president of the U.S.A. Biden has already declared the plan to recommit to Paris Agreement, which doesn't have any relevance without the biggest partner - seen from the microeconomic as well as from the macroeconomic point of view. This new positive message would have substantial influence on emission allowances trading through increasing the demand (for usage of a trading system) or a pressure to find optimal regulation instrument for air pollution.

Our research since 2005 (since emission allowances are traded) up to now leads to the conclusion that this approach to minimize emissions is ineffective. On the basis of all these considerations, it can be stated that it distorts business environment and within 15 years, the emission allowances trading system didn't bring stabilization of the environment or any environmental gains. Finally, it is noteworthy that this economic instrument distorts statements of financial position of polluters, public companies, as well as government accounting. 
It is evident that the accounting is able to find methods to capture a chosen instrument that politicians and environmentalists will come up with to reduce air emissions. It can recognise these instruments in financial statements or describe them in notes and commentaries. As mentioned above, after the unfortunate end of the IFRIC 3, in accounting practice there are different approaches that are applied differently. However, it is therefore necessary to evaluate first how these pseudo-assets, subsidies, compensations, other taxes not only distort the business environment and whether disproportionate sanctions do not bring about further problems that translate into increase in energy prices, but above all to unify and argue their content, definition and, preferably, one, and only one, unequivocal accounting capture, based on a correct understanding of the economic substance. In view of the above, it is not even possible to draw any other conclusion.

\section{Acknowledgement}

This work was supported by the project Development of the Private collage Economic Studies as a school for the 21 st century in the field of accounting and taxes of the European Union and the Ministry of Education, Youth and Sports. Project No. according to MS 2014+: CZ.02.2.69 / 0.0 / 0.0 / 16_015 / 000237.

\section{References}

[1] BŘEZINOVÁ, H., 2019. Rozumíme účetní závěrce podnikatelů. Wolters Kluwer ČR, a.s. 3. edition. 213 p. ISBN: 978-80-7598-488-3 (broch.), 978-80-7598-489-0 (e-pub.), 9787598-490-6 (pdf), 978-80-7598-491-3 (mobi).

[2] RYNEŠ, P., 2019. Podvojné účetnictví a účetní závěrka. Praha: Nakladatelství ANAG, 1079 p. ISBN 978-80-7554-192-5.

[3] MACKENZIE, D., 2008. Material Markets: How Economic Agents are constructed. Oxford: Oxford University Press, 240 p. ISBN: 978-0-19-927815-2.

[4] Emisní obchodování., 2020. In: Ministerstvo životního prostředí [online]. [seen. 2020-0208]. Available under: https://www.mzp.cz/cz/emisni_obchodovani

[5] JEŘÁBKOVÁ, J., 2018. Vývoj ceny emisní povolenky v letošním roce. Biom.cz [online]. 2018-11-24 [seen. 2020-06-18]. Available under: <https://biom.cz/cz/odborneclanky/vyvoj-ceny-emisni-povolenky-v-letosnim-roce>. ISSN: 1801-2655.

[6] MAJLING, E., Spojené královstvi pokračuje vpř́pravách vlastního systému pro obchodování semisními povolenkami. [seen 2020-06-04]. Available under: https://oenergetice.cz/zahranicni/spojene-kralovstvi-pokracuje-pripravach-vlastnihosystemu-obchodovani-emisnimi-povolenkami

[7] KYOTO PROTOCOL TO THE UNITED NATIONS FRAMEWORK CONVENTION ON CLIMATE CHANGE https://www.mzp.cz/C1257458002F0DC7/cz/kjotsky_protokol/\$FILE/OMVanglicky_protokol-20081120.pdf

[8] KJÓTSKÝ PROTOKOL K RÁMCOVÉ ÚMLUVĚ ORGANIZACE SPOJENÝCH NÁRODÜ O ZMĚNĚ https://www.mzp.cz/C1257458002F0DC7/cz/kjotsky_protokol/\$FILE/OMVcesky_protokol-20081120.pdf

[9] PAŘǏŽSKÁ DOHODA - Rámcová úmluva Organizace spojených národů o změně klimatu. [seen 2020-06-04]. Available under: https://eur-lex.europa.eu/content/parisagreement/paris-agreement.html?locale $=\mathrm{cs}$ 
[10] RUF, J. A., 2017. A policy analysis of the EU Emissions Trading System and its crisis. Hochschule für Wirtschaft und Recht Berlin. Available under: https://www.econstor.eu/bitstream/10419/149891/1/879452927.pdf ISBN 1869-6406

[11] TAUCHMANOVÁ, B., 2017. Evropský systém obchodování s emisními povolenkami (EU ETS), jeho fungování a úspěšnost. Praha. Univerzita Karlova.

[12] VOLF, P., 2020. Emisní povolenky stojí 25 eur/tCO2: Jak na nich vydělat? Available under: https://www.cenyenergie.cz/emisni-povolenky-cena-burza/\#/promo-gas-mini

[13] VRBOVÁ, Z., MŽP navrhuje kompenzovat energeticky náročné podniky částkou 2,4 miliardy. [seen. 2020-06-03]. Available under: https://oenergetice.cz/energetickalegislativa-cr/mzp-navrhuje-kompenzovat-energeticky-narocne-podniky-castkou-24miliardy

[14] WARWICK, P. and Ng C. (2012) The 'Cost' of Climate Change: How Carbon Emissions Allowances are Accounted for Amongst European Union Companies. Australian Accounting Review, 22(1): 54-67.

[15] World Bank Group. 2019. State and Trends of Carbon Pricing 2019. ISBN (electronic): 978-1-4648-1435-8. Available under: https://openknowledge.worldbank.org/handle/10986/31755

[16] Act No. 563/1991 Sb., Accounting Act - Zákon o účetnictví. Ministerstvo financí [online]. [seen June 20, 2020]. Available under: https://www.zakonyprolidi.cz/cs/1991-563

[17] Act No. 383/2012 Sb., Allowances Act - Zákon o obchodování s povolenkami na emise skleníkových plynů. Ministerstvo životního prostředí [online]. [seen June 20, 2020]. Available under: https://www.zakonyprolidi.cz/cs/2012-383

[18] Regulation No. 500/2002 Sb., Entrepreneurs Accounting Regulation - Vyhláška, kterou se provádějí některá ustanovení zákona č. 563/1991 Sb., o účetnictví, ve znění pozdějších předpisů, pro účetní jednotky, které jsou podnikateli účtujícími v soustavě podvojného účetnictví. Ministerstvo financí [online]. [seen June 20, 2020]. Available under:https://www.zakonyprolidi.cz/cs/2002-500

[19] Regulation No. 192/2013 Sb., o stanovení formulářủ žádostí o přidělení povolenek pro provozovatele letadla a o vydání povolení k emisím skleníkových plynů. Ministerstvo životního prostředí. [online]. [seen June 20, 2020]. Available under: https://www.zakonyprolidi.cz/cs/2013-192

[20] EU Directive - Směrnice Evropského parlamentu a Rady 2003/87/ES ze dne 13. ř́jjna 2003 o vytvoření systému pro obchodování s povolenkami na emise skleníkových plynů ve Společenství a o změně směrnice Rady 96/61/ESText s významem pro EHP. [seen June 20, 2020]. Available under: https://eur-lex.europa.eu/legalcontent/CS/TXT/?qid=1578642026844\&uri=CELEX:32003L0087

[21] Commission Regulation - Nařízení Komise (EU) č. 601/2012 ze dne 21. června 2012 o monitorování a vykazování emisí skleníkových plynů podle směrnice Evropského parlamentu a Rady 2003/87/ES Text s významem pro EHP. [seen June 20, 2020]. Available under: https://eur-lex.europa.eu/legalcontent/CS/TXT/?qid=1578403021996\&uri=CELEX:32012R0601 